\title{
Memories from the margins: violence and counter-narratives - introduction
}

\author{
Nina Parish and Daniele Rugo
}

\section{In memory of Lokman Slim}

Abstract: This supplementary issue looks at how informal, often unrecognised, memory practices are used to deal with the legacy of violent conflict as a way to heal trauma, demand justice, and build sustainable peace. By drawing on case studies from Bosnia and Herzegovina, Colombia, India, Lebanon, Northern Ireland, Rwanda, Sri Lanka, Syria, and Vietnam, the articles examine informal practices of memorialisation that challenge amnesia and hegemonic discourses of conflict by creating spaces for dialogue and exchange.

Keywords: Memory practices, violent conflict, amnesia, justice, dialogue.

Note on the authors:

Nina Parish is Professor of French and Francophone Studies at the University of Stirling. She works on representations of difficult history, the migrant experience, and multilingualism in the museum space. She is also an expert on the interaction between text and image in the field of modern and contemporary French Studies and has published widely on this subject, in particular, on the poet and visual artist, Henri Michaux. She is Co-Investigator on the British Academy-funded Memories from the Margins project (https://www.memoriesmargins.com). https://orcid.org/0000-0001-8606-9524

Dr Daniele Rugo is an award-winning filmmaker and Reader in Film at Brunel University London and currently a Visiting Senior Fellow at the LSE and Visiting Professor at Sciences Po. His research focuses on conflict and sustainable peace and has been funded by AHRC, ESRC, and British Academy. About a War is his latest feature documentary. He is the author of two monographs, one edited volume, and several journal articles. He is Principal Investigator on the British Academy-funded Memories from the Margins project (https://www.memoriesmargins.com).

https://orcid.org/0000-0001-8606-9524

(C) The author(s) 2021. This is an open access article licensed under a

Creative Commons Attribution-NonCommercial-NoDerivs 4.0 Unported License 
In societies affected by armed conflict, learning from the past can prevent violence, promote justice, and contribute to sustainable peace. For these societies, however, collective memory is often fragmented, monopolised by political elites, and mirrors societal inequalities. State institutions enforce amnesia over the past and dictate who is allowed to speak. The heritage of the conflict remains unresolved and can fuel new outbursts of violence and instability. Citizens therefore strive to bypass and challenge hegemonic narratives and state-enforced silence by devising bottom-up practices that create spaces for dialogue and advance demands for justice and accountability. This Journal of the British Academy supplementary issue looks at how these informal, often unrecognised, practices are used to deal with memory as a way to heal trauma, demand justice, and build sustainable peace. By drawing on case studies from Bosnia and Herzegovina, Colombia, India, Lebanon, Northern Ireland, Rwanda, Sri Lanka, Syria, and Vietnam, the articles examine informal practices of memorialisation that challenge amnesia and hegemonic discourses of conflict by creating spaces for dialogue and exchange.

This issue emerges out of the project, Memories from the Margins, ${ }^{1}$ funded by the British Academy, focusing on the memory work produced in informal archives and oral histories from Lebanon's Civil War (1975-90) and Syria's ongoing conflict (2011present) to create a documentary film, an online archive, and teaching material, as well as producing research articles from our findings. In Lebanon, countering amnesia is seen as a way to delegitimise the sectarian rhetoric that- together with the persistence of cultural violence and martial infrastructures - fuel the sense that the war has not ended. In Syria, forms of narrative production beyond state-sanctioned ones can become mechanisms for transitional justice and help foreground local perceptions overlooked by an overly internationalised process. This issue and the project therefore shift the focus on the agency of local actors and local field dynamics.

Our project's aims are to study (a) how bottom-up approaches to memorialisation can be inclusive, address citizens' lack of agency, and contribute to sustainable peace in contexts marked by obstruction from formal institutions; (b) the efficacy of personal archives in challenging amnesia or hegemonic narratives of conflict and advancing demands for justice; (c) the sensory, aesthetic dimensions of the heritage produced by conflict; (d) the link between the ways in which heritage of conflict is dealt with and the emergence of new violence; and (e) the transfer of unconventional practices and methods from one context to another. The articles in this issue engage with these aims in a variety of ways using a number of different case studies from autobiographical narratives about child refugees from Rwanda and Vietnam to the use of oral histories in an exhibition developed at the Ulster Museum in Belfast. They are not all

${ }^{1}$ http://www.memoriesmargins.com 
traditional academic articles written by researchers employed by universities. We are interested in different forms of responses to these ideas as attested by pieces written by memory activists, such as Salma Kahale, the Founder and former Executive Director of the non-profit Syrian civil organisation, Dawlaty. They in no way provide an exhaustive overview of using informal memory practices to deal with difficult history but instead suggest some theoretical frameworks, such as Anna Cento Bull and Hans Lauge Hansen's agonistic memory, ${ }^{2}$ Viet Thanh Nguyen's just memory, ${ }^{3}$ or Michael Rothberg's multidirectional memory ${ }^{4}$ and implicated subjectivity, ${ }^{5}$ and methodological practices such as object biographies and oral histories that could be applied to or used in different contexts. They all engage with and reflect on the complex interface between collective memory and personal recollections of war and violence.

We begin with three articles that deal with our project's case studies. Carmen Hassoun Abou Jaoude (University of Saint Joseph, Beirut) and Daniele Rugo (Brunel University London) are both researchers on the Memories from the Margins project. Their article, 'Marginal memories of Lebanon's Civil War: challenging hegemonic narratives in a small town in North Metn', focuses on the significance of the 'hidden public culture' formed by individual memories of violent conflicts, with particular reference to the Lebanese Civil War (1975-90). ${ }^{6}$ Moving from an understanding of memory as a terrain through which individuals can produce counter-hegemonic narratives, and contest authoritarian governance and repressive memory scripts, their article examines how intimate memories can contribute to understanding the power relations that structure official memories of war. By shifting focus to individual memories, everyday practices, and material culture, exemplified here by interviews with inhabitants of a small town in North Metn, a district in Mount Lebanon, the article emphasises the importance of lived experiences of conflict as a way to challenge the normative construction of political subjectivities in a sectarian state and therefore become sites of resistance. Broadly speaking, Abou Jaoude and Rugo advocate for the use of personal memories and informal archives in research into violent conflicts as a way to challenge the exceptional-spectacular character of war and broaden our understanding of conflict's different lived experiences.

The case study of Lebanon and the idea of personal memories disrupting the state's hegemonic production of history and memory are further explored in the article by Lynn Hodeib (independent researcher), 'Objects of transgenerational memory: challenging hegemonic historical narratives of war in Lebanon', which takes

\footnotetext{
${ }^{2}$ Cento Bull \& Hansen (2016).

${ }^{3}$ Nguyen (2017).

${ }^{4}$ Rothberg (2009).

${ }^{5}$ Rothberg (2019).

${ }^{6}$ Abou Jaoude \& Rugo (2021).
} 
as its focus objects embedded in the domestic life of the first and second generations of people who witnessed the Lebanese Civil War. ${ }^{7}$ The article analyses stories surrounding two objects - a tray and a bowl - that survived the war, and took on layers of memory later heard and retold by the second generation. These objects demonstrate ways in which the legacy of intergenerational memory is produced and transmitted - and how these alternative spaces and stories inform present struggles, including the October 2019 revolution. Hodeib firstly discusses how material objects operate as intergenerational symbols of the experiences of war and as media for the process of narrativisation. She then goes on to explore the role of the material as a witness to what resists language and as a locus to memory's temporality. In the final section, Hodeib examines the affective dimension of the material object as it provokes an opening to narration and challenges linear understandings of history. This study of material and domestic objects seeks stories that resist closure, and is essential to understanding today's struggle against the Lebanese political class.

Attention is shifted from the memory work of everyday objects to that done through oral history in Syria and the important work carried out by the non-profit civil organisation, Dawlaty, in the article by Salma Kahale, 'Oral history as a method of promoting inclusive and gender-sensitive justice' ${ }^{8}$ The Syrian Oral History Archive programme, developed by Dawlaty, aims to ensure collective memory of the Syrian conflict is built based on truth telling, recognition of marginalised communities' experiences, and mutual understanding. This online platform encompasses the voices of ordinary Syrians - with a focus on women and marginalised youth - and acts to recount both individual and collective recollections of the 2011 Syrian Uprising and the Syrian conflict thereafter. Created to build a collective narrative on the experience of the last decade in Syria, the modality of oral history testimony has itself become a tool in promoting justice and empowering citizens. The impact of historical documentation in this form both validates the lived experiences of a generation of Syrian citizens, and empowers local communities, who play a direct role both in the methodology of collecting testimony and in producing community art.

The power of oral history in uncovering, recording, and exhibiting informal memories of violence is further explored by Chris Reynolds (Nottingham Trent University), in his article 'The symbiosis of oral history and agonistic memory: Voices of 68 and the legacy of the past in Northern Ireland'. ${ }^{9}$ Reynolds offers a reflection on the potency of combining oral history and agonistic memory. Via the specific example of a recent collaboration between Reynolds and National Museums Northern Ireland

\footnotetext{
${ }^{7}$ Hodeib (2021).

${ }^{8}$ Kahale (2021).

${ }^{9}$ Reynolds (2021).
} 
on the subject of 1968, he argues that the symbiotic relationship between this methodological approach and theoretical underpinning provides a potentially effective response to the current and pressing challenge of managing the legacy of the Troubles as part of the Northern Irish peace process. The success of this approach in the particular and difficult context of Northern Ireland suggests that there are potential lessons for other post-conflict societies coming to terms with the challenges of their own difficult pasts.

George Wilkes (King's College London) examines alternative ways for post-conflict societies to deal with the past at a local level, in his article 'Cross-communal acts of commemoration designed to promote peace at a local level in Bosnia-Herzegovina'. ${ }^{10}$ Wilkes describes two distinct senses in which local remembrance activities are used to build peace in Bosnia-Herzegovina: to counter nationalist conflict narratives and to demonstrate cross-communal recognition on the local level. The existing literature on such activism in Bosnia-Herzegovina foregrounds the objective conditions in which the combination of memory activism and peacebuilding is necessary as a counter to the uses made of remembrance by the main ethnonationalist parties to justify their divisive rule. The article draws on the concepts of Michael Rothbergmultidirectional memory and implicated subjectivity-to show how the divergent forms of local peacebuilding and memory activities imply choices which also have a subjective, relational element. To enable the reader to understand these choices, the article first reviews the historical, political, and social conditions faced by activists. Secondly, it explores ways in which the subjective, relational dimension of these choices are also keys to understanding ways in which their variety and their engagement with local realities are not captured in objectivising literature on peacebuilding and memory work.

Adriana Rudling (Universidad del Rosario, Bogota) and Lorena Vega Dueñas (Pontificia Universidad Javeriana, Bogota) continue this exploration of community memory work and activism in Colombia, in their article 'Liquid graves and meaning activism in the Colombian armed conflict: the "bottom-up" recovery and memorialisation of victims of forced disappearance'. ${ }^{11}$ The use of non-burial methods in the context of the Colombian armed conflict can be traced to the early 1950s. Focusing on the period starting in the 1980s, Rudling and Vega Dueñas aim to define the agency of the community members of Puerto Berrío (Department of Antioquia) engaged in the recovery of human remains from the Magdalena River. Covering three main elements, namely the preservation of the remains salvaged from these liquid graves, their 'baptism' using fabricated names, and the 'adoption' of their souls in exchange

\footnotetext{
${ }^{10}$ Wilkes (2021).

${ }^{11}$ Rudling \& Vega Dueñas (2021).
} 
for small favours, they argue that this complex practice is inherently political. This community-level meaning activism arises as a consequence of the harm-amplifying reality of a pathological state. It is a form of resistance to (in)formal rules of necrogovernmentality imposed by the non-state armed groups, the Catholic Church, and, most importantly, by the state. They highlight the double role of the state, on the one hand, as a rule-of-law agent that rallies for the equal treatment and protection of its citizens and, on the other, a fragmented anomic agent that persecutes specific groups and individuals placed outside this realm of protection to be treated as internal enemies'. Victims recognise both the ill disposition of the state and the precarity of the legal-bureaucratic administration of forced disappearance but continue to challenge both through these individual and community-level resistance practices as well as mobilise legally and politically to hold the state to account. They conclude that the 2016 Final Peace Agreement represents a renewed opportunity for a 'virtuous state', where the element of victim (and citizen) participation or inclusion in the transitional justice mechanisms arising from it seeks to dignify and recognise their struggle for justice and historic resistance.

Jaideep Gupte (University of Sussex) and Syeda Jenifa Zahan (University of Sussex), in their article 'Silent cities, silenced histories: subaltern experiences of everyday urban violence during COVID-19', bring these engagements with informal memories of violence into the here and now by reflecting on how institutional responses to COVID-19 can further hinder the emergence of informal memories and the role of the researcher in this process. ${ }^{12}$ The public health containment measures put into place in response to COVID-19 have precipitated a significant epistemic and ontological shift in 'bottom-up' and 'action-oriented' approaches in development studies research. 'Lockdown' necessitates physical and social distancing between the research subject and researcher. This raises legitimate concerns around the extent to which 'distanced' action-research can be inclusive and address citizens' lack of agency. Top-down regimes to control urban space through lockdown in India have not stemmed the experience of violence in public spaces. Some experiences of violence have dramatically intensified, while others have changed in unexpected ways. Drawing on their experiences of researching the silent histories of violence and memorialisation of past violence in urban India over the past three decades, Gupte and Zahan argue that the experience of subaltern groups during the pandemic is not an aberration from their sustained experiences of everyday violence predating the pandemic. Exceptionalising the experiences of violence during the pandemic serves to silence past histories and disenfranchises long struggles for rights in the city. At the same time, however, the authors argue that research practices employed to interpret the experience

\footnotetext{
${ }^{12}$ Gupte \& Zahan (2021).
} 
of urban violence during lockdown in India need to engage the changing nature of infrastructural regimes, as they seek to control urban space, and as subaltern groups continue to mobilise and advocate, in new ways.

The issue closes with two articles which consider the potential of literature and the visual arts to engage with, represent, and express informal memories of violence. Ashwiny O. Kistnareddy (University of Cambridge), in her article "Nothing ever dies": memory and marginal children's voices in Rwandan and Vietnamese narratives', examines narratives which reclaim memory as personal and as a collective plea to understand the structural discrepancy at play from the child who is victim of war. ${ }^{13}$ She analyses the memoir of a Tutsi refugee child ${ }^{14}$ and an autobiographical narrative by a Vietnamese refugee in Canada ${ }^{15}$ to gauge the extent to which such narratives create their own memorial spaces and in so doing reclaim their marginal memories and centre them. Ultimately Kistnareddy tests Viet Thanh Nguyen's theory that memory can be just and that, in this ethical recoding of memory, the humanity and inhumanity of both sides are underlined.

Hasini Haputhanthri (International Centre for Ethnic Studies, Colombo), in her article 'The past in our art: confronting the contemporary in an ancient society', ${ }^{16}$ explores the works of contemporary Sri Lankan artists. While the use of ancient iconography in modern and contemporary art is a fairly common approach among artists, not much attention has been paid to understanding how local artists make choices between tradition and modernity, history and memory, negotiating past and the present at personal and communal spheres. In Sri Lanka, ideas and representations of the past play a central role in social discourses. Not only that, there are competing versions of the past: historic past - the domain of historians, archaeologists, and museologists - and 'practical past' - the domain of writers, filmmakers, and artists, which, is also the past of the 'common man'. By analysing the works of Hanusha Somasunderam and Jagath Weerasinghe, the article illustrates how artists investigate the past in unique ways, different from how figures such as historians, archaeologists, and museologists deal with 'the past'. Haputhanthri argues that these artists' works offer intricate palimpsests of the historic and mnemonic strata; and that their practice is an essential way in which societies understand and express their past in relation to their present.

Whilst this Journal of the British Academy supplementary issue is diverse in methods, geographical contexts, and theoretical engagements with memorialisations

\footnotetext{
${ }^{13}$ Kistnareddy (2021).

${ }^{14}$ Habonimana (2019).

${ }^{15}$ Thúy (2010).

${ }^{16}$ Haputhanthri (2021).
} 
of violence, all the contributions share an understanding of memory as an active force that keeps shaping the present. In the cases discussed here, memory work becomes a form of activism that renegotiates power structures, challenges hegemonic legacies, and becomes a vehicle for accountability and justice. Precisely because of this, memory work often has a disruptive and oppositional significance, requiring as much an effort of recall as one of creation, a rewriting of time. This work requires courage and it is clear that the stakes can be very high for those who make of memory a matter of justice.

\section{References}

Abou Jaoude, C.H. \& Rugo, D. (2021), 'Marginal Memories of Lebanon's Civil War: Challenging Hegemonic Narratives in a Small Town in North Metn', Journal of the British Academy, 9(s3): 11-27. https://doi.org/10.5871/jba/009s3.011

Cento Bull, A. \& Hansen, H.L. (2016), 'On Agonistic Memory', Memory Studies, 9(4): 390-404. https://doi.org/10.1177/1750698015615935

Gupte, J. \& Zahan, S.J. (2021), 'Silent Cities, Silenced Histories: Subaltern Experiences of Everyday Urban Violence During COVID-19', Journal of the British Academy, 9(s3): 139-155. https://doi.org/10.5871/jba/009s3.139

Habonimana, C. (2019), Moi, le dernier Tutsi (Paris, Plon Récit).

Haputhanthri, H. (2021), 'The Past in Our Art: Confronting the Contemporary in an Ancient Society', Journal of the British Academy, 9(s3): 173-195. https://doi.org/10.5871/jba/009s3.173

Hodeib, L. (2021), 'Objects of Transgenerational Memory: Challenging Hegemonic Historical Narratives of War in Lebanon', Journal of the British Academy, 9(s3): 29-50.

https://doi.org/10.5871/jba/009s3.029

Kahale, S. (2021), 'Oral History as a Method of Promoting Inclusive and Gender-sensitive Justice', Journal of the British Academy, 9(s3): 51-71. https://doi.org/10.5871/jba/009s3.051

Kistnareddy, A.O. (2021), “Nothing Ever Dies”: Memory and Marginal Children's Voices in Rwandan and Vietnamese narratives', Journal of the British Academy, 9(s3): 157-172. https://doi.org/10.5871/jba/009s3.157

Nguyen, V.T. (2017), Nothing Ever Dies: Memory and the Vietnam War (Cambridge, MA, Harvard University Press). https://doi.org/10.4159/9780674969889

Reynolds, C. (2021), 'The Symbiosis of Oral History and Agonistic Memory: Voices of 68 and the Legacy of the Past in Northern Ireland', Journal of the British Academy, 9(s3): 73-94. https://doi.org/10.5871/jba/009s3.073

Rothberg, M. (2009), Multidirectional Memory: Remembering the Holocaust in the Age of Decolonization (Stanford, CA, Stanford University Press).

Rothberg, M. (2019), The Implicated Subject: Beyond Victims and Perpetrators (Stanford, CA, Stanford University Press). https://doi.org/10.1515/9781503609600

Rudling, A. \& Vega Dueñas, L. (2021), 'Liquid Graves and Meaning Activism in the Colombian Armed Conflict: the 'Bottom-up' Recovery and Memorialisation of Victims of Forced Disappearance', Journal of the British Academy, 9(s3): 121-137. https://doi.org/10.5871/jba/009s3.121

Thúy, K. (2010), Ru (Montreal, Liana Lévi).

Wilkes, G.R. (2021), 'Cross-communal Acts of Commemoration Designed to Promote Peace at a Local Level in Bosnia-Herzegovina', Journal of the British Academy, 9(s3): 95-119.

https://doi.org/10.5871/jba/009s3.095 
To cite the article: Nina Parish and Daniele Rugo (2021), 'Memories from the margins: violence and counter-narratives-introduction', Journal of the British Academy, 9(s3): $1-9$.

DOI https://doi.org/10.5871/jba/009s3.001

Journal of the British Academy (ISSN 2052-7217) is published by

The British Academy, 10-11 Carlton House Terrace, London, SW1Y 5AH

www.thebritishacademy.ac.uk 
